\title{
Goal Setting and Fear of Failure among Indigent Adolescents
}

\author{
Dr. Vandana Jain ${ }^{1}$, Anmol Joy Antony ${ }^{2}$ \\ ${ }^{1}$ Assistant. Professor \& HOD, Department of PG Studies and Research in Psychology, S.D.M College, (Autonomous) Ujire- 574 \\ 240 \\ ${ }^{2}$ Ms. Anmol Joy Antony, Research student, Department of PG Studies and Research in Psychology, S.D.M College, \\ (Autonomous) Ujire- 574240 \\ 11vandanajainm@gmail.com, ${ }^{2}$ anu02081997@gmail.com
}

\begin{abstract}
Goal setting is the action plan designed by an individual to achieve his/her goals while fear of failure is a motive to avoid failure in most of evaluative situations based on anticipatory shame upon failure of the person in concern. This study aims at finding correlation between goal setting and fear of failure among indigent adolescents of Kalina, Mumbai. For this, the sample size of 87 indigent students was taken among which 53 were females and 34 were males. Goal Setting Formative Questionnaire by Gaumer Erickson, A.S. \& Noonan, P.M (2018) and Performance Failure Appraisal Inventory (PFAI) by David E. Conray, Ph.D. were used, which has high reliability. Exploratory research design was used for the study and this study gives further scope for parents, counselors, educational sectors and social workers to give needful opportunities to indigent population and to acknowledge their levels of Goal setting and reduce fear of failure.
\end{abstract}

Keywords

Goal setting, gender difference, indigent adolescents, fear of failure.

Article Received: 10 August 2020, Revised: 25 October 2020, Accepted: 18 November 2020

\section{Introduction}

\section{Goal Setting}

Goal setting is the action plan designed by an individual which motivates an individual towards a goal. (Grant, Antony M., 2012). Goal setting can also be defined as focusing on your own improvement by identifying goals that are meaningful and based on data. (Guamer Erickson \& Noonan, 2016). Students who establish their own goal, take the responsibilities of their goals, such goal oriented behavior is an outcome of goal setting which empowers children. (Hasna Abu Khalid \& Dr. Mary Ann Hollignsworth, 2017).

\section{Theory of goal setting}

According to Lock \& Latham (2002), there is a direct correlation between conscious goals and their effect on action. The theory given by Lock and Latham states that written goals and performance have a direct relationship. The studies done by Lock and Latham showed that goals provide standards to compare work and provide feedback regarding competence and continued motivation for learning.

\section{Goal setting and Low Socio Economic Status (SES)}

Dweck and colleagues (2014) have mentioned that goal setting activities are valuable for children with low socio economic status (SES); this helps children develop higher academic tenacity and enthusiasm.

It is been found that both gender and Socio Economic Status(SES) are believed to shape and may influence the change of goals and their effect on each other over time. (Sarah J. Beal \& Lisa J. Crockett). Children belonging to low
SES lack adequate learning facilities. (Becker \& Tomes, 1979). Parents with low SES have stated that it has been hard for children to make children realize their life goals and education goals due to scarcity of financial resources. (Drummond \& Stipek, 2004), on the other hand children of low SES have stated that they are ready to work hard and smart in order to meet their goals. (Hasna Abu Khalid \& Dr. Mary Ann Hollignsworth, 2017)

\section{Goal setting among Adolescents}

The present study focuses on goal setting among adolescents living in low SES. Adolescence is a period where young people's future aspirations and expectations begin to crystallize. (Sarah J. Beal \& Lisa J. Crockett). With the increase of age people feel less confident, in control and capable of accomplishing goals. (Berry \& West, 1993).

\section{Fear of failure}

Failure is the neglect or omission of expected or required action (Oxford Dictionary). It is the fear which hinders a person from achieving the set goals.(Mindtools content team). When it is in its extreme form then it is termed as Atychiphobia (Jacob Olesen), whereas, the present research only focuses on the normal tendencies of an individual to be afraid of performing actions directed towards the goal. When an individual imagines all negative outcomes of an action that leads to the failure of the planned goal it has emotional, cognitive and behavioral reaction that can be observed. Fear of failure has an influence over the type of goal, the type of strategy used, and in marking the standards of success. Individuals having higher level of fear of failure tend to focus their efforts on prevention of loss than achieving gains. (Theo Tsaousides Ph.D.) 
According to the author Sherrie Hurd, the causes for fear of failure is, lack of confidence, perfectionism, personalization, comparison with others work, and childhood issues such as strict parenting. Keeping things simple, being in the present moment, and accepting fear as path towards success can be few ways of overcoming fear of failure (Sherrie Hurd, 2019).

\section{Fear of failure and age}

Age is another factor which can have an influence on fear of failure, as the present study focuses on adolescents, it is important to state that a research done by Marco Correia shows that preadolescents(12-14 years) have less fear failure than adolescents(15- 20 years). (Marco Correia, et.al, 2017).

\section{Fear and low socio economic status}

Social factors play an important role in development of fear of failure, it was seen that people belonging to low socio economic status tend to show higher level of fear of failure than middle and upper socioeconomic status. (Vivek Tiwar, 2018). Further, the growth of country's economy has an impact as, it is observed that, when the economy of country is growing, fewer people fear to fail.( Prof. Dr. Richard Geibel, 2014).

\section{Fear of Failure and Goal setting}

The researcher, Theo Tsaousides Ph.D., says that based on the outcome, there are two approaches shown by people, that is promotion and prevention goals. when a person achieves positive outcome, it is called as promotion goals, on the other hand, prevention goals are characterized by less self-determination, lower engagement, disorganized approaches to goal pursuit and anxiety.

Fear of failure leads to creation of prevention goals, outcome of which is underestimation of performer's efforts, reducing confidence in setting goals.Fear of Failure (FoF) is cause for that hinders people from setting goals. Individuals having FoF have self-doubts while setting goals, this can be due to the past experiences of failure which embarrasses the individual. (Austin Bollinger, 2019)

People do not try to attain their goal due to fear of failure; such people may lack belief in their potentials, (Douglas Vermeeren, (ND)).

Theorists of achievement goal and intrinsic motivation reveal that there two primary orientations towards goals, that are mastery and performance. Performance goals can be further partitioned into independent approach and avoidance approach. While setting goals strive to avoid incompetence indicating that these individuals are driven by fear of failure( Elaine Houston,2019).

\section{Slum}

Slums are usually characterized by urban wastes, poverty, illiteracy, and unemployment and diseases due to lack of cleanliness, nutrition and basic needs (UN-Habitat, 2003)

Originally the word slum was evolved in 1845 in East End of London, as a British slang meaning 'room', which later was termed as back slum, meaning street of poor
people.(Douglas Harper,2001). The word slum has negative connotations, and usage of this word to an area can be an attempt to undermine that land. (Alfredo Stein). Hence, the research uses a replaceable word for 'Slum', that is indigent

\section{Rationale of the study}

There are impoverished population in India which is lacking the basic education for which there are governmental policies and non-governmental organizations to improvise their lifestyle. It becomes important to see the psychological aspects to analyze their mental wellbeing and readiness for attaining the desired level of education. Goal setting and fear of failure are two such variables taken into consideration to see the levels of these variables and how it affects the gender of indigent population. In accordance to the results of these study possible changes for the betterment of education system, at national or international level, can be provided to indigent population.

\section{Method}

\section{Research question}

1. What is the level of goal setting and fear of failure among indigent adolescents?

2. Is there a significant relationship between goal setting and fear failure among indigent adolescents?

\begin{abstract}
Aim
To study the relationship between goal setting and fear of failure among indigent adolescents.
\end{abstract}

\section{Objectives}

1. To analyze the level of goal setting and fear of failure among indigent adolescents.

2. To find the relation between goal setting and fear of failure.

\section{Hypothesis}

$\mathrm{H}_{0}$ - There is no significant relationship between goal setting and fear of failure among indigent adolesccents.

\section{Variables}

Independent variable - Gender

Dependent variable - Goal setting and fear of failure

\section{Operational Definition}

1. Fear of failure - A motive to avoid failure in most of evaluative situations based on anticipatory shame upon failure of the person in concern.

2. Goal setting- Focusing on one's own improvement by identifying goals that are meaningful and data based.

3. Indigent Adolescent- Any individual falling under the age of 10-19 years, living in the impoverished area. (generally known as people living in slum) 


\section{Participants}

Participants included 87 indigent adolescent students of Kalina, Mumbai among which 53 were females 34 were males. The age of the participants ranged from 10-18. The annual income of the participants ranged from 8,000 to 10,000 Rs. per annum. The participants above the income of 10,000 Rs. per annum were excluded.

Sample

Purposive sampling method was opted for the study

Sample composition

\begin{tabular}{ccc}
\hline Groups & No. of participants & Total \\
\hline Males & 34 & 87 \\
\hline Females & 53 &
\end{tabular}

\section{Research Design}

Exploratory research design was used for the study.

\section{Inclusion Criteria}

1. Participants living in slum area of Mumbai from past 10 years, from the date of assessment.

2. Participants who are read and understand English.

\section{Exclusion Criteria}

1. Participants having family income more than 10,000 per month.

2. Participants above the age of 19 years were excluded.

Tools

1. Goal setting formative questionnaire - this questionnaire is developed by Gaumer Erickson, A.S. \& Noonan, P.M. in the year 2018. It consists of 19 items. The questionnaire has high reliability of 0.91 and adequate validity.

The questionnaire measures the goals in three major components, goals that are meaningful to the individual, goals that focus on one's personal improvement, and goals based on data. Meaningful goals include items related to short and long term goals that help the individual to meet various purpose of life (e.g., I set long term goals such as of earning a college degree or entering a career). Personal goals include questions of goals that lead to self improvement and healthy competition. (E.g., even if I lose a competition, I am pleased if I have improved). Data based includes questions of setting goals based on prior life experiences \& focusing on the outcomes of planning the goals (e.g., when setting a goal, I think about my past success and failures).

2. Performance Failure Appraisal Inventory (PFAI) short form was used - this questionnaire was developed by David E. Conroy, Ph.D., (Department of Kinesiology,
College of Health \& Human Development, Pennsylvania State University), in the year 2003. It consists of 5 items. The questionnaire has reliability of 0.72 and factorial validity.

\section{Procedure}

The Purpose of the study was explained to the participants. The participant's willingness to participate in the study was ascertained after the establishment of rapport. The participants were briefed about the Goal setting questionnaire and PFAI (short form) separately and were provided with clear instructions. There was a gap of 15 minutes provided between the administrations of two. After the completion of administration, the scoring was done for the responses obtained and results were obtained.

\section{Statistical analysis}

- Descriptive statistics - Mean and Standard deviation

- Inferential statistics- Pearson's Correlation.

\section{Ethical Consideration}

- Consent was taken from the participants

- Data was used only for the research purpose.

- Confidentiality was maintained

\section{Results and discussion}

In the study descriptive statistics of mean and standard deviation was used to find the levels of goal setting and fear of failure. Pearson's correlation was used to test the relationship between goal setting and fear of failure.

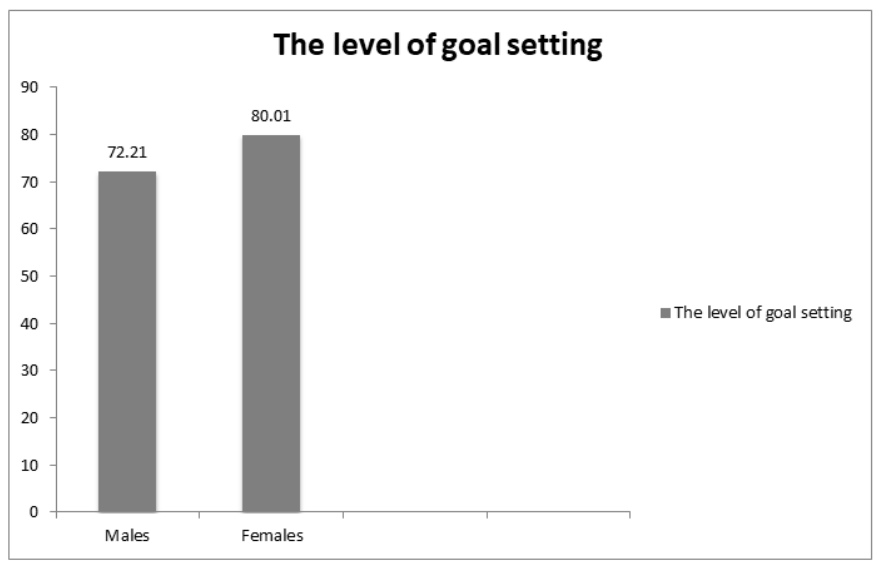

Figure 1- shows the gender difference obtained in the level of goal setting 


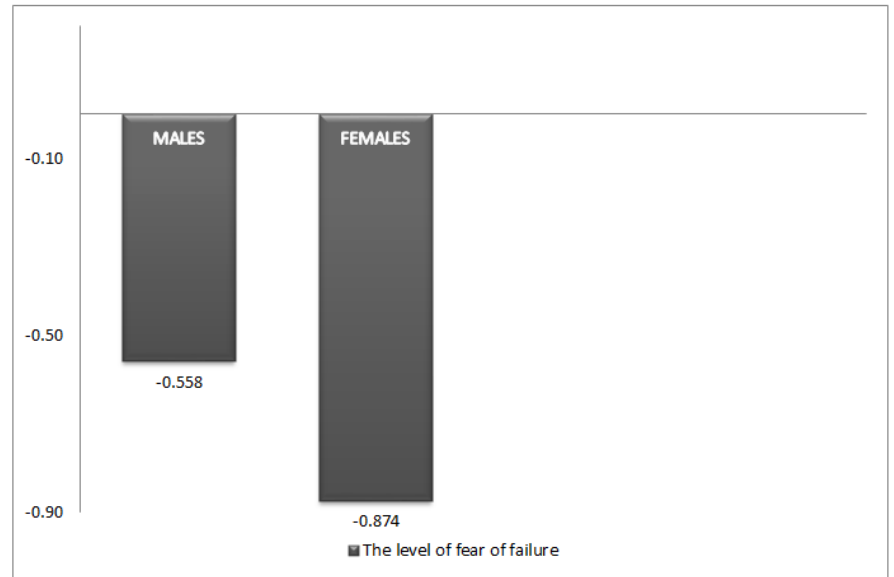

Figure 2- shows the gender difference obtained in the level of fear of failure.

The figure 1 shows that females have high level of goal setting than males. The research entitled, The Goal Setting Components: A Study Of Serbian EFL Learners, by Aleksandar M. Zivanovic \& Mirjana D. Subotin on a sample of 100 participants shows that females obtain high scores in 3 aspects of goal setting, viz., commitment, self-efficacy and autonomy, and low score on goal conflict, the research states that female students are more committed, self-efficacious, have less goal conflicts and exhibit more autonomy.

The figure 2 shows that females have less levels of fear of failure when compared to males. This data contradicts the research done by Krista L. et.al . which finds that females have higher scores on fear of failure when compared to males.

Table 1- Shows the relationship between goal setting and fear of failure.

$$
\text { r-value p-value }
$$

Goal setting

$$
-0.435^{* *}
$$

Fear of failure

The above table shows the correlation of fear of failure and goal setting; there is a negative correlation in fear of failure and goal setting with a value of -0.435 which is significant at 0.01 level. The Pearson's correlation analysis gives a negative correlation between fear of failure and goal setting which indicates that if the level of goal setting increases there would be decrease in the level of fear of failure and vice versa. Here the null hypothesis which states that there is no significant relationship between goal setting and fear of failure, is been rejected.
A research done by J.M Wikman, R. Steler, M. Melzer (2012), shows that an intervention program on goal setting can reduce the fear of failure.

\section{Conclusions}

- With the increase fear of failure there is decrease in goal setting.

- The researchers see that though there are less of resources to the population, it sets aim towards accomplishment of it of goals. The negative correlation obtained in the levels of goal setting and fear of failure gives an insight that enhancing the levels of goal setting and reducing the levels of fear of failure will have a positive outcome. Hence adolescents need to consider goal setting and fear of failure as some of the important aspects of better decision making and career planning.

\section{Limitations}

- $\quad$ A sample size of 87 students was used, which can be increased.

\section{Implications}

This research data can be used by parents, teachers, counselors and social workers to in built facilitations to enhance goal setting and reduce fear of failure among adolescents

Scope

- $\quad$ There is scope for intervention studies on the same sample to study the effects of practicing goal setting and its impact over fear of failure.

The subscales of the questionnaires of goal setting and fear of failure can assessed for detailed analysis of each factor under the variables.

\section{Acknoledgements}

I would take the privilege of expressing my sincere gratitude to all those who have supported me in successful completion of this research.

I thank Prof. S. Satheeshchandra, Principal, SDM College, Ujire for providing me the opportunity to conduct this research.

I extend my gratitude to Dr. Vandana Jain, Assistant Professor and Head of the Department of Post Graduate Studies and Research in Psychology, SDM PG Centre for providing the congenial platform for conducting this research and for her timely guidance and valuable suggestions.

I am grateful to Dr. Vandana Jain, Mrs. Navyashree GC, Mrs. Varsha Malagi, Dr. Maheshbabu, Ms. Sayujya for their unconditional support as external resource persons.

I thank Mr. Rajendra Tawade, the CEO of Smile Foundation, Kalina, Mumbai, for allowing me conduct survey on the indigent adolescents. 
I would like to thank all my friends and classmates who have helped me directly and indirectly in the completion of this study.

I am grateful to my parents for being my backbone throughout the journey of my dissertation.

\section{References}

[1] Hurd, S. (2020). 5 Things That Cause Fear of Failure and How to Overcome It. Retrieved 2 March 2020, from https://www.learning-mind.com/fear-offailure-causes-solutions/

[2] Tsaousides Ph.D., T. (2020). Why Fear of Failure Can Keep You Stuck. Retrieved 2 March 2020, from https://www.psychologytoday.com/us/blog /smashing-the-brainblocks/201712/whyfear-failure-can-keep-you-stuck

[3] Overcoming Fear of Failure: Facing Fears and Moving Forward. Mindtools.com. (2020). Retrieved 2 March 2020, from https://www.mindtools.com/pages/article/f ear-of-failure.htm.

[4] Olesen, J. (2020). Fear of Failure Phobia Atychiphobia or Kakorrhaphiophobia. FEAROF.NET. Retrieved 2 March 2020, from https://www.fearof.net/fear-offailure-phobia-atychiphobia/.

[5] Failure | Definition of Failure by Lexico. Lexico Dictionaries | English. (2020). Retrieved 2 March 2020, from https://www.lexico.com/en/definition/failu re.

[6] Correia, Marco \& Rosado, António \& Serpa, Sidónio \& Ferreira, Vitor. (2017). Fear of failure in athletes: Gender, age and type of sport differences. Revista Iberoamericana de Psicologia del Ejercicio y el Deporte. 12. 185-193.

[7] Geibel, P. (2020). How do certain Factors affect the fear of Failure in Entrepreneurship? Regional comparison of the Factors that drive the Fear of taking the Risks of starting a Business. Digital Library. Retrieved 2 March 2020, from https://dl4.globalstf.org/productspage/proceedings/bizstrategy/how-docertain-factors-affect-the-fear-of-failurein-entrepreneurship-regional-comparison- of-the-factors-that-drive-the-fear-oftaking-the-risks-of-starting-a-business/.

[8] Heinzel B. Sc., J., Askari, D., \& Geibel, P. (2014). How do certain Factors affect the fear of Failure in Entrepreneurship?. 4Th Annual International Conference On Business Strategy And Organizational Behaviour (Bizstrategy 2014). https://doi.org/10.5176/2251-1970_ie14.08

[9] Crossman, A. (2020). An Introduction to Socioeconomic Status. ThoughtCo. Retrieved 2 March 2020, from https://www.thoughtco.com/socioeconomi c-status-3026599.

[10] Stages of Adolescence. HealthyChildren.org. (2020). Retrieved 2 March 2020, from https://www.healthychildren.org/English/a ges-stages/teen/Pages/Stages-ofAdolescence.aspx.

[11] Wayback Machine. Web.archive.org. (2020). Retrieved 2 March 2020, from https://web.archive.org/web/20110206143 558/http://www.unhabitat.org/downloads/d ocs/4625_51419_GC\%2021\%20What\%20 are\%20slums.pdf.

[12] Journals.sagepub.com. (2020). Retrieved 2 March 2020, from https://journals.sagepub.com/doi/pdf/10.11 77/095624788900100201.

[13] Tsaousides Ph.D., T. (2020). How to Conquer Fear of Failure. Psychology Today. Retrieved 2 March 2020, from https://www.psychologytoday.com/us/blog /smashing-the-brainblocks/201801/howconquer-fear-failure.

[14] Houston, E. (2020). What is Goal Setting and How to Do it Well. PositivePsychology.com. Retrieved 2 March 2020, from https://positivepsychology.com/goalsetting/.

[15] Bollinger, A. (2020). Learn How to Overcome the Five Fears of Goal Setting. Daily New Year's. Retrieved 2 March 2020, from https://www.dailynewyears.com/blog/over come-the-five-fears-of-goal-setting/. 
[16] Burnstein, E. (1963). Fear of failure, achievement motivation, and aspiring to prestigeful occupations. The Journal Of Abnormal And Social Psychology, 67(2), 189-193. https://doi.org/10.1037/h0046230

[17] Wikman, J., Stelter, R., Melzer, M., Hauge, M., \& Elbe, A. (2014). Effects of goal setting on fear of failure in young elite athletes. International Journal of Sport And Exercise Psychology, 12(3), 185-205.

https://doi.org/10.1080/1612197x.2014.88 1070

[18] DeCharms, R., \& Dave, P. (1965). Hope of success, fear of failure, subjective probability, and risk-taking behavior. Journal Of Personality And Social Psychology, 1(6), 558-568. https://doi.org/10.1037/h0022021

[19] Elliot, A., \& Thrash, T. (2004). The Intergenerational Transmission of Fear of Failure. Personality And Social Psychology Bulletin, 30(8), 957-971. https://doi.org/10.1177/014616720326202 4

[20] Jackaway, R., \& Teevan, R. (1976). Fear of failure and fear of success. Sex Roles, 2(3), 283-293. https://doi.org/10.1007/bf00287656

[21] (2020). Retrieved 2 March 2020, from https://s3.amazonaws.com/academia.edu.d ocuments/35569391/Qualittive_report_ar ticle.pdf?response-contentdisposition=inline $\% 3 \mathrm{~B} \% 20$ filename $\% 3 \mathrm{D}$ Water_and_Sanitation_in_Mumbai_s_Slu ms_E.pdf\&X-Amz-Algorithm=AWS4HMAC-SHA256\&X-AmzCredential=AKIAIWOWYYGZ2Y53UL3 A\%2F20200227\%2Fus-east1\%2Fs3\%2Faws4_request\&X-Amz-

Date $=20200227 \mathrm{~T} 183423 Z \& X-A m z-$

Expires $=3600 \& X-A m z-$

SignedHeaders $=$ host $\& X-A m z-$

Signature $=5 \mathrm{e} 82694 \mathrm{~b} 8 \mathrm{~b} 8 \mathrm{e} 259 \mathrm{ccd} 06171360$ f348889ca27a04abd5db495c2588bad773c 012.

[22] Pdfs.semanticscholar.org. (2020). Retrieved 2 March 2020, from https://pdfs.semanticscholar.org/1efe/28ed 3908c00bbdf6e7336a852ce77d7e3551.pdf https://s3.amazonaws.com/academia.edu.d ocuments/56926118/44-

Tarannum_Siddiqui.pdf?response-contentdisposition $=$ inline $\% 3 \mathrm{~B} \% 20$ filename\%3DP ROBLEMS OF DROP-

OUT_STUDENTS_IN_INDIAN.pdf\&XAmz-Algorithm=AWS4-HMAC-

SHA256\&X-Amz-

Credential=AKIAIWOWYYGZ2Y53UL3

A\%2F20200227\%2Fus-east-

$1 \% 2 \mathrm{Fs} 3 \% 2 \mathrm{Faws} 4$ request\&X-Amz-

Date $=20200227 \mathrm{~T} 181721 \mathrm{Z} \& \mathrm{X}-\mathrm{Amz}-$

Expires $=3600 \& X-A m z-$

SignedHeaders $=$ host $\& X-A m z-$

Signature $=c 9 c d c 4 d 5 a 96$ caafeb $896 b c 2 f f 98$ 1667ab18a1f056a97d722ee098fd031b72fe 8.

[23] Carroll, A., Gordon, K., Haynes, M., \& Houghton, S. (2012). Goal Setting and Self-Efficacy Among Delinquent, At-Risk and Not At-Risk Adolescents. Journal Of Youth And Adolescence, 42(3), 431-443. https://doi.org/10.1007/s10964-012-9799$\mathrm{y}$

[24] Lee, L. H. (1998). Goal orientation, goal setting, and academic performance in college students: An integrated model of achievement motivation in school settings. Dissertation Abstracts International Section A: Humanities and Social Sciences, 59(6-A), 1905.

[25] Fuchs, L., Fuchs, D., \& Deno, S. (1985). Importance of Goal Ambitiousness and Goal Mastery to Student Achievement. Exceptional Children, 52(1), 63-71. https://doi.org/10.1177/001440298505200 108

[26] Rukmini Banerji (Mar. 4-10, 2000). Poverty And Primary Schooling : Field Studies From Mumbai And Delhi, Economic and Political Weekly, Vol. 35, No. 10, pp. 795-802

[27] Behavioral Research Press. Grambling State University, Math Department, P.O. Box 1191, Grambling, LA 71245. Tel: 318-274-2425; Web site: http://www.gram.edu/education/erq/ 
[28] M. Grant, A. (2012). An integrated model of goal-focused coaching: An evidencebased framework for teaching and practice. International Coaching Psychology Review, 7(1750-2764),pp.146165.

[29] Abu Khalid, H. and Ann Hollingsworth, D. (2017). Effect of Economic Level on Students Goal Setting. International Journal of Humanities and Social Science Invention, 6(9), pp.76-84.

[30] Bahar, M., Uğur, H. and Asil, M. (2018). Social achievement goals and students' socio-economic status: Cross-cultural validation and gender invariance. Issues in Educational Research, 28(3).

[31] Smithers, S. (2015). Goals, Motivation and Gender. Department of Economics, University of Leicester, Leicester, LE1 7RH.

[32] Henningsen, J. (2019). How Men \& Women Differ in Goal Setting - Jeanne Henningsen - Leadership Coach \& Consultant. [online] Jeanne Henningsen Leadership Coach \& Consultant. Available at: http://jeannehenningsen.com/how-menwomen-differ-in-goal-setting/ [Accessed 1 Nov. 2019].

[33] Beal, S. J., \& Crockett, L. J. (2013). Adolescents Occupational and Educational Goals: A Test of Reciprocal Relations. Journal of applied developmental psychology, 34(5), 219-229. doi:10.1016/j.appdev.2013.04.005

[34] Gaumer Erickson, A.S. \& Noonan, P.M. (2018). Goal setting formative questionnaire. In The skills that matter: Teaching interpersonal and intrapersonal competencies in any classroom (p. 179). Thousand Oaks, CA: Corwin.

[35] Seijts, G., Latham, G., Tasa, K. and Latham, B. (2004). Goal Setting And Goal Orientation: An Integration Of Two Different Yet Related Literatures. Academy of Management Journal, 47(2), pp.227-239.

[36] Saajanaho, M. (2019). Personal Goals in Old Age Relationships with Resources in
Life, Exercise Activity, and Life-Space Mobility. University Library Jyväskylä.

[37] West, R., Welch, D. and Thorn, R. (2001). Effects of goal-setting and feedback on memory performance and beliefs among older and younger adults. Psychology and Aging, 16(2), pp.240-250.

[38] Heidemeier, H. and Staudinger, U. (2014). Age differences in achievement goals and motivational characteristics of work in an ageing workforce. Ageing and Society, 35(4), pp.809-836.

[39] PositivePsychology.com. (2019). A Look at the Psychology of Goal Setting (Incl. 3 Research Findings). [online] Available at: https://positivepsychology.com/goalsetting-psychology/ [Accessed 1 Nov. 2019].

[40] Živanović, A. and Subotin, M. (2018). The Goal Setting Components: A Study Of Serbian Efl Learners. Методички видици, 9(9), p.235.

[41] Home Care Assistance. (2019). The Importance Of Setting Goals - At Any Age I Home Care Assistance. [online] Available at: https://homecareassistance.com/blog/theimportance-of-setting-goals-at-any-age [Accessed 1 Nov. 2019].

[42] Dweck, C. S., M. Walton, G. and L. Cohen, G. (2014). Academic Tenacity: Mindsets and Skills that Promote Longterm Learning.. Seattle: Bill \& Melinda Gates Foundation.

[43] Drummond, K. V., \& Stipek, D. (2004). Low-Income Parents' Beliefs about Their Role in Children's Academic Learning. The Elementary School Journal, 104(3), 197-213.

[44] Berry, J. and West, R. (1993). Cognitive Self-efficacy in Relation to Personal Mastery and Goal Setting across the Life Span. International Journal of Behavioral Development, 16(2), pp.351-379.

[45] Wieland, J., kumar, J., doe, j., Arsid, V., Logan, J., Evans, O. and kelamiye, B. (2019). What is Goal-Setting Theory? [online] GoStrengths!. Available at: 
https://gostrengths.com/what-is-goalsetting-theory/ [Accessed 1 Nov. 2019].

[46] Effects of goal setting on fear of failure in young elite athletes. (2020). Retrieved 4 December 2020, from https://doi.org/10.1080/1612197X.2014.88 1070 